\title{
Schopenhauer, Nietzsche, a eternidade da vida da Vontade e a incólume força criadora do espírito dionisíaco
}

\author{
Schopenhauer, Nietzsche, the eternity of life of the Will and the unscathed \\ creative force of the Dionysian spirit
}

\author{
Renato Nunes Bittencourt \\ Doutor em Filosofia pelo PPGF-UFRJ \\ Membro do Grupo de Pesquisa Spinoza \& Nietzsche \\ Professor do Curso de Especialização em Pesquisa de Mercado e Opinião da UERJ \\ Professor da Universidade Candido Mendes e da Faculdade CCAA \\ E-mail: renatonunesbittencourt@gmail.com
}

\begin{abstract}
Resumo: Neste artigo estabelecemos uma convergência filosófica entre Schopenhauer e Nietzsche acerca da questão ontológica da eternidade da vida natural, não obstante a finitude da individualidade regida pelas categorias do espaço e do tempo. Demonstramos que Schopenhauer, não obstante receber a alcunha de pessimista, apresenta uma visão de mundo que permite a superação do desgosto da existência mediante a hipótese de que apenas a vida individual se anula no evento da morte, e não as condições de possibilidades da vida, a Vontade. Nietzsche, por sua vez, argumenta que a vida, apesar de sua finitude, é digna de ser vivida em sua plenitude, pois é apenas a configuração individual que se dissipa pelo acontecimento da morte, jamais a potência dionisíaca que se encontra presente em todas as formas individuais.
\end{abstract}

Palavras-Chave: Vontade; Eternidade; Dionisíaco.

Abstract: In this article we have a philosophical convergence between Schopenhauer and Nietzsche about the ontological question of eternity of natural life, notwithstanding the finitude of individuality governed by the categories of space and time. We demonstrate that Schopenhauer, nevertheless receive the nickname of pessimistic, presents a worldview that allows overcoming the grief of existence upon the hypothesis that only the individual life disappears in the event of death, and not the conditions of possibility of life, the desire. Nietzsche, in turn, argues that life, despite its finitude, is worthy of being lived in its fullness, as it is only the individual configuration dissipates by the event of the death, never the Dionysian power that is present in every individual shapes.

Keywords: Will; Eternity; Dionysian.

Em memória de minha mãe Sandra Maria

Nunes Bittencourt (1957-2013) 


\section{Introdução}

A reflexão filosófica sobre a questão da finitude humana e uma compreensão positiva de nossa existência mesmo que marcada por tal limitação encontra nas obras de Schopenhauer e de Nietzsche uma valiosa contribuição que agrega intimamente elementos ontológicos, cosmológicos e éticos. A compreensão da finitude da vida humana é talvez fonte de desespero para grande parte da humanidade, independentemente de sua formação cultural e orientação religiosa. A busca por respostas acerca do que aguardaria o homem após sua extinção corporal é recorrente em todas as civilizações. As grandes religiões orientais e ocidentais formularam crenças consoladoras para seus fieis, de modo que as inconscientes aspirações metafísicas dos indivíduos em relação ao pretenso estado de Além-morte encontraram razoável consolação espiritual, talvez evitando que indivíduos sequiosos por hipóteses espirituais acerca do destino do ser humano mergulhassem em uma espécie de grande vazio existencial, projetando nas vivencias religiosas um razoável conforto teológico. Entretanto, como essa questão é abordada pelos indivíduos sectários do ateísmo ou por discursos que negam toda teleologia na condução da existência humana? Para muitos ateístas, a morte física é a extinção plena de toda vida, e nada mais há após esse fenômeno. Todavia, mesmo discursos filosóficos associados aos princípios ateístas propuseram hipóteses que se caracterizam por disposições holísticas em suas explanações, como se porventura houvesse uma vida cósmica para além das configurações extensivas individuais. Nessas condições, tanto Schopenhauer como Nietzsche fornecem teorias sobre a eternidade da vida intensiva para além das considerações puramente materiais, de modo que ambos assim contribuem para uma ruptura com o pessimismo niilista.

\section{Schopenhauer e a eternidade da Vontade}

Um dos grandes mistérios da existência humana reside no que se encontra após o término da vida física. O medo da finitude ou as expectações ansiosas sobre a continuidade da consciência após a dissolução do corpo assolam grande parte da 
humanidade, decorrendo daí a necessidade metafísica do consolo religioso como forma de se atenuar o mal-estar existencial decorrente da compreensão da efemeridade da vida terrena. Todavia, Schopenhauer postula a hipótese de que não existe vida espiritual após a dita morte, ou seja, qualquer dimensão abstrata na qual a alma humana se estabeleceria, seja para vivenciar a beatitude divina, seja para sofrer os tormentos por suas faltas, seja para se purgar dos seus vícios, seja para aguardar seu retorno ao mundo da carne. A vida consciente nada mais é que um hiato entre o Nada anterior ao existir e o Nada posterior ao existir. A vida individual então é um hiato entre o Não-ser e o Nãoser. Para Schopenhauer,

Onde existe Vontade existirá vida, mundo. Portanto, à vontade de vida a vida é certa, e, pelo tempo que estivermos preenchidos de vontade de vida, não precisamos temer por nossa existência, nem pela visão da morte. Decerto vemos o indivíduo nascer e perecer. Entretanto, o indivíduo é apenas fenômeno, existe apenas para o conhecimento pertencente ao princípio de razão, para o principio individuationis. Da perspectiva desse conhecimento, o indivíduo ganha a sua vida como uma dádiva, surge do nada, e depois sofre a perda dessa dádiva através da morte, voltando ao nada ${ }^{1}$.

Entretanto, a vida individual tal como compreendida pela massa humana é apenas uma faceta da vida eterna da Vontade, esta sim a verdadeira vida. Quando a consciência filosófica desponta na mente humana, compreende-se que existe uma vida metafísica, eterna, para além das limitações fenomênicas. Conforme argumenta Schopenhauer,

Um tempo infinito fluiu antes do meu nascimento, o que eu era durante todo esse tempo? - Em termos metafísicos talvez eu pudesse responder: "Eu fui sempre eu, em verdade todos aqueles que durante aquele tempo diziam eu, eram eu mesmo" .

Por conseguinte, se a consciência individual existe apenas no ato de encarnação da Vontade em um corpo delimitado espaço-temporalmente, o mesmo não se aplica ao núcleo vital que se encontra nessa mesma Vontade, ontologicamente eterna. Como a

\footnotetext{
${ }^{1}$ SCHOPENHAUER, A. WWV/MVR, I, § 54, p. 358.

${ }^{2}$ SCHOPENHAUER, A. WWV/MVR, II, "Metafísica da Morte”, p. 66. 


\section{RENATO NUNES BITTENCOURT}

intelectualidade humana comum é limitada em sua compreensão metafísica da realidade, ela se torna incapaz de assimilar intuitivamente a ideia de que a essência da vida permanece mesmo após a morte material do ser individual. A vida humana se configura como uma espécie de experimentação lúdica da natureza, para a qual convergem todos os seres no decorrer do ciclo vital de nascimento e perecimento. Segundo Schopenhauer,

\footnotetext{
Ora, se a grande mãe envia tão sem cuidado seus filhos desprotegidos de encontro aos mil perigos ameaçadores, isso só pode ser porque ela sabe que, caso eles caiam, recaem em seu ventre, onde estão protegidos e, por isso, a sua queda é apenas uma brincadeira. Ela se comporta com os homens do mesmo jeito que com os animais. Sua expressão portanto se estende ao fato de que a vida e morte do indivíduo lhe são indiferentes. De acordo com isso deveria, num certo sentido, ser assim para nós: pois nós mesmos somos a natureza ${ }^{3}$.
}

A consciência arcaica da humanidade originária reconhece no símbolo do círculo a inexistência de uma finalidade ulterior na existência, proclamando que toda a vida faz parte de um processo incessante de renovação e dissolução dos seus caracteres. Quando a moralidade metafísica se incrustou no discurso religioso, o círculo foi quebrado em prol da crença na trajetória linear da vida humana rumo ao transcendente, um percurso nascido no âmbito físico e continuado no plano metafísico, como se ocorresse o aprimoramento contínuo do ser vivente no decorrer das eras. Contudo, como Schopenhauer não coaduna com o viés teleológico da existência, não havendo assim nenhuma meta a ser alcançada, ou seja, nenhum estágio superior ao qual a alma humana deve aspirar a chegar mediante a sua pretensa evolução espiritual:

Sempre e por toda parte o círculo é o autêntico símbolo da natureza, porque ele é o esquema do retorno. Este é de fato a forma mais geral na natureza, que ela adota em tudo, desde o curso das estrelas até a morte e nascimento dos seres orgânicos, e apenas por meio do qual, na torrente incessante do tempo e de seu conteúdo torna-se possível uma existência permanente, isto é, uma natureza ${ }^{4}$.

\footnotetext{
${ }^{3}$ SCHOPENHAUER, A. WWV/MVR, II, "Metafísica da Morte", p. 79.

${ }^{4}$ SCHOPENHAUER, A. WWV/MVR, II, "Metafísica da Morte”, p. 84. 
A vida individual é apenas uma faceta ínfima da grande vida da espécie, essa sim a matriz mantenedora de todos os indivíduos que nascem e morrem organicamente a cada dia. A extinção física de um ser vivente é condição indispensável para que a vida holística se perpetue. Se porventura não existisse o evento da morte física do ser individual as condições de possibilidade da vida estariam já extintas. Quem nasce, floresce, amadurece, envelhece e morre é apenas o indivíduo, nunca a espécie, tampouco a Vontade. De acordo com Schopenhauer,

A espécie é o que vive por todo tempo, e é na consciência da sua imortalidade e da sua identidade que os indivíduos existem satisfeitos. A vontade de vida aparece no presente sem fim, porque este é a forma de vida da espécie, que por isso não envelhece, mas permanece sempre jovem ${ }^{5}$.

O despertar da consciência holística granjeia ao sujeito do conhecimento a serenidade e a certeza de que há uma potência criadora que não se dissolve jamais através da morte individual; a morte do fenômeno é assim uma ilusão cognitiva, apenas o término imediato de um ser circunscrito pelo princípio de individuação; sua energia vital se perpetua na vida da espécie. Schopenhauer postula que

A convicção profunda de nossa indestrutibilidade pela morte, que, como atestam os inevitáveis escrúpulos de consciência quando ela se aproxima, cada vez traz no fundo do próprio coração, depende inteiramente da consciência de nossa originariedade e eternidade ${ }^{6}$.

A consciência egocêntrica, focada apenas na certeza do eu, forja a ilusão de que a vida individual é o centro axiológico de todas as relações do sujeito, colocando os demais viventes e toda a realidade circundante sob a órbita dos seus preceitos valorativos. Mera ilusão promovida pelo princípio de individuação, que impede ao sujeito de conhecimento ampliar sua consciência existencial e se reconhecer na plenitude da vida que habita o todo vivente. Para a mente aflita que aspira conservar sua existência consciente após a morte física, é um duro golpe contra suas pretensões individualistas a constatação de que o cerne de sua consciência se dissolve após o seu

\footnotetext{
${ }^{5}$ SCHOPENHAUER, A. WWV/MVR, II, "Metafísica da Morte”, p. 87.

${ }^{6}$ SCHOPENHAUER, A. WWV/MVR, II, "Metafísica da Morte”, p. 102.
} 


\section{RENATO NUNES BITTENCOURT}

perecimento orgânico. Para a mente que adquiriu a reflexão filosófica e a inerente capacidade de contemplação da unicidade da vida, reconhece-se que o indivíduo faz parte de um grande todo que é a espécie, e essa consciência se conforta nessa certeza vital. Segundo Schopenhauer

Com a morte perde-se de fato a consciência, mas não aquilo que a produziu e a manteve. A vida se extingue, mas não se extingue com ela o princípio de vida, que nele se manifestou. Por isso, um sentimento seguro diz a todo homem que há nele algo absolutamente imperecível e indestrutível ${ }^{7}$.

Quando a morte é, nós nada somos, quando nós somos, a morte nada é. Tal jogo de ideias poderia auxiliar a consciência humana a se desvencilhar do temor pela extinção física proporcionada pelo evento da morte. Se a consciência se dissolve no processo da morte, não há mais nada o que temer, pois toda percepção e cognição se encerram na extinção física da chama da vida que se manifesta no organismo individual. Conforme Schopenhauer

O temor da morte depende, em grande parte, da falsa aparência de que, neste instante, o eu desaparece e o mundo permanece. Mas é antes o contrário que é verdadeiro: o mundo desaparece, enquanto o núcleo mais íntimo do eu, o sustentáculo e produtor de cada sujeito, em cuja representação somente o mundo possuía sua existência, permanece ${ }^{8}$.

Nesse contexto, cabe uma importante interlocução com a questão da reencarnação, mais precisamente, metempsicose e palingenesia, doutrinas adotadas pelas tradições religiosas orientais como o Hinduísmo e o Budismo, assim como pelo Orfismo grego e por algumas vertentes filosóficas influenciadas por este último (pitagorismo e platonismo), perpassando ainda a construção moderna da doutrina espírita. Schopenhauer considera que de fato não ocorre a sucessiva transmigração da alma no decorrer das eras na encarnação em corpos distintos (metempsicose), mas a permanência da energia constituinte (isto é, a Vontade) desse ser vivo, em outros viventes (palingenesia). Dessa maneira, o poder que engendra a vida é eterno,

\footnotetext{
${ }^{7}$ SCHOPENHAUER, A. WWV/MVR, II, "Metafísica da Morte", p. 118.

${ }^{8}$ SCHOPENHAUER, A. WWV/MVR, II, "Metafísica da Morte", p. 126.
} 
inextinguível, girando continuamente o circulo da vida de criação e destruição de todas as configurações existenciais. Schopenhauer afirma que

Como vontade de vida que se afirma, o homem tem a raiz de sua existência na espécie. Pelo que então a morte é o perder de uma individualidade e o obter de outra, por conseguinte uma mudança de individualidade sob a condição exclusiva de sua própria vontade. Pois apenas nesta reside a força eterna, que pôde produzir a sua existência justamente com o seu eu, mas que, devido à sua constituição, não pode mantê-lo 9 .

A Vontade, ao se individualizar como fenômeno, instiga todo indivíduo a se empenhar pela obtenção de sua própria conservação. Uma das formas encontradas pela Vontade para tal objetivo consiste na atração sexual entre o homem e a mulher que, inconscientemente, iludidos pela beleza do parceiro amoroso e por outros requintes de sedução, nada mais visam que perpetuar a existência da Vontade através da geração de um novo ser vivo. Para Schopenhauer,

Todo enamorar-se, por mais etéreo que possa parecer, enraíza-se unicamente no impulso sexual, e é apenas um impulso sexual mais bem determinado, mais bem especializado e mais bem individualizado no sentido rigoroso do termo [...] O fim último de toda disputa amorosa, seja ela com borzeguim ou coturno, é realmente mais importante que todos os outros fins da vida humana, e, portanto, merece por inteiro a seriedade profunda com a qual cada um o persegue. De fato, o que aí é decidido não é nada menos do que a composição da próxima geração ${ }^{10}$.

Usualmente dizemos que amor e morte são circunstâncias incompatíveis; na verdade, são instâncias indissociáveis, pois a Vontade cria a atração sexual entre os viventes para que possam perpetuar a espécie, mantendo assim a continuidade da vida nos seus múltiplos indivíduos; entretanto, a finitude encerra a existência particular, inserindo o fluxo vital latente nesse ser novamente no seio da natureza, que assim se apropria novamente dessa energia para distribui-la em novas configurações existenciais, plasmadas justamente através do amor, isto é, atração sexual entre os seres viventes:

\footnotetext{
${ }^{9}$ SCHOPENHAUER, A. WWV/MVR, II, "Metafísica da Morte”, p. 128.

${ }^{10}$ SCHOPENHAUER, A. WWV/MVR, II, “Metafísica do Amor”, p. 7; p. 8. 


\section{RENATO NUNES BITTENCOURT}

Cada novo ser nascido entra em cena fresco e lépido na nova existência e a frui como um presente, embora não haja e não possa haver nisso nada de dado. Sua fresca existência é paga com a velhice e a morte de um defunto que sucumbe, mas que continha o germe indestrutível, do qual nasceu esse novo ser: ambos são um único ser, demonstrar a ponte entre os dois seria com certeza a solução de um grande enigma ${ }^{11}$.

Podemos então afirmar que a metafísica da morte elaborada por Schopenhauer em verdade converge para uma metafisica da vida eterna, não como a proposta pela teologia cristã, mas como uma constatação natural da própria perpetuação da vida em todas as expressões vitais que habitam o seio da natureza. Dessa maneira, permanece uma consciência filosófica para além de qualquer otimismo vazio ou pessimismo prático, mas uma serenidade interior em que se sustenta a mentalidade filosófica capaz de ver a grande totalidade da vida manifestada nos múltiplos fenômenos individuais.

\section{O trágico em Nietzsche e a vida eterna do impulso dionisíaco}

As obras de juventude de Nietzsche, em especial $O$ nascimento da Tragédia, manifestam profundas convergências axiológicas com o pensamento schopenhaueriano. Em linhas gerais, a noção de princípio de individuação preconizada por Schopenhauer para representar as categorias fenomênicas do espaço e do tempo foram apropriadas por Nietzsche para a configuração do principio apolíneo da bela aparência, enquanto o conceito schopenhaueriano de Vontade encontra na teoria nietzschiana sua convergência com o princípio dionisíaco, o "Uno Originário" propiciador de todas as formas de vida. Postas estas questões preliminares, podemos afirmar que algumas questões éticas latentes no discurso nietzschiano de $O$ nascimento da Tragédia, em especial o problema da superação do pessimismo prático mediante a compreensão do caráter eterno da existência - não obstante a dissolução da vida individual - se enraíza imediatamente no sistema filosófico schopenhaueriano.

Para Nietzsche, a visão dionisíaca da existência nos faz ver que "somos os ditosos viventes, não como indivíduos, mas como o uno vivente, com cujo gozo

\footnotetext{
${ }^{11}$ SCHOPENHAUER, A. WWV/MVR, II, "Metafísica da Morte”, p. 132.
} 
procriador estamos fundidos" $"$. A vida se engendra na obscuridade e nas profundezas da terra, onde a semente morre e se destrói, para posteriormente eclodir com uma força alegre sobre a terra. O espírito dionisíaco imerge o indivíduo nas forças telúricas, dotadas de uma energia criadora cuja percepção humana, usualmente limitada, é incapaz de conceber na sua intensa plenitude. O núcleo vital da terra encontra expressão imediata no ventre materno, pois de ambos brota a expressão da vida em sua mais rica profusão, manifestando sempre o instante mágico da singularidade, pois todo vivente, ao se individualizar na configuração extensiva, representa sempre uma nova parcela da grande vida cósmica, que jamais repete uma figuração. A terra é mãe comum que engendra, ilumina e recolhe de novo em seu seio os seres vivos.

Podemos então dizer que, na perspectiva dionisíaca, não haveria a "morte" propriamente dita, pois que todo tipo de forma de vida, ao perder as suas funções orgânicas, é apropriada pela natureza, que transforma então essa matéria em energia dinâmica a ser assimilada por outros corpos. ${ }^{13}$ A terra se nutre da matéria dos corpos devolvidos ao seu seio materno, acolhendo-os mais uma vez para que, numa ocasião posterior, possam ser novamente desprendidos de seu núcleo unificador, proporcionando mais uma vez a instauração da configuração individual, até o momento em que a sua energia motriz venha a se dissipar. Ésquilo, nas Coéforas, apresenta a ideia dionisíaca de que o sangue sorvido pela terra é o nutriente de todos os seres, e a terra depois recebe deles de novo o gérmen fecundador, acontecimento misterioso, que pode ser entendido tanto como a energia vital que engendra um novo ser no ventre feminino, como também a matéria extensiva que é assimilada pelo grande organismo telúrico quando o corpo "morto" de um ser entra em contato com a terra. ${ }^{14}$ Por conseguinte, o rito dionisíaco revela ao ser humano a compreensão intuitiva de que o ciclo da vida engloba necessariamente a morte. Para Nietzsche,

\footnotetext{
12 NIETZSCHE, F. O nascimento da Tragédia, § 17, p. 102-103.

${ }^{13}$ Neste momento, vale utilizarmos o comentário de Karl Kerenyi em Dioniso, p. 177, segundo o qual a morte e a destruição da vida seriam parte da própria vida, refletindo assim a percepção global da epifania dionisíaca de que existe uma grande unidade entre todas as expressões da natureza, mesmo que biologicamente "mortas".

${ }^{14}$ ÉSQUILO. As Coéforas, vs. 81-82.
} 


\section{RENATO NUNES BITTENCOURT}

(...) Somente nos mistérios dionisíacos, na psicologia do estado dionisíaco, expressa-se o fato fundamental do instinto helênico - sua "vontade de vida". Que garantia o heleno para si com esses mistérios? A vida eterna, o eterno retorno da vida; o futuro, prometido e consagrado do passado; o triunfante Sim à vida, acima da morte e da mudança; a verdadeira vida, como continuação geral mediante a procriação, mediante os mistérios da sexualidade. Para os gregos, então, o símbolo sexual era o símbolo venerável em si, o autêntico sentido profundo no interior da antiga religiosidade. Todo pormenor do ato da procriação, da gravidez, do nascimento, despertava os mais elevados e solenes sentimentos. Na doutrina dos mistérios a dor é santificada; as "dores da mulher no parto" santificavam a dor em geral - todo vir-a-ser e crescer, tudo o que garante o futuro implica a dor... Para que haja o eterno prazer da criação, para que a vontade de vida afirme eternamente a si própria, tem de haver também a "dor da mulher que pare" 15

A "promessa na vida" que se revela como o sentido profundo do simbolismo das atividades dionisíacas encerra como significado uma bendição trágica da existência: a vida exuberante retorna e ressurge eternamente da destruição e da dor que ela própria inelutavelmente conjura. Toda expressão de vida decorre de uma fusão entre os estados de prazer e de dor, até mesmo o jubiloso ato de nascimento de um novo ser.

A semente deve ser enterrada para que um vegetal possa posteriormente florescer. Agregando no seu ventre o princípio vital, a potência materna da natureza faz o gérmen vivenciar uma metamorfose simbólica de vida-morte, pois que no momento em que a semente está contida nas suas entranhas, ela está metaforicamente morta, e torna a "viver" quando é devolvida para a natureza na sua nova configuração expressiva. Uma vez que a dor fora divinizada no rito dionisíaco, também a morte o foi, pois ela não resulta na supressão da criatividade da vida, mas sim na sua mais bela continuidade, pois efetivamente não há dissociação entre morte e vida no núcleo plástico da natureza. Da mesma maneira que a experiência dionisíaca proporciona uma compreensão afirmativa da própria morte, retirando-lhe os seus traços pesarosos e tristonhos, ela também desfere um golpe fortíssimo contra as especulações metafísicas de um possível mundo pós-morte, pois que nada lhe é mais estranho do que a crença esperançosa numa dimensão transcendente, radicalmente separada desse mundo em que vivemos. Conforme os dizeres de Jean-Pierre Vernant e Pierre Vidal-Naquet,

\footnotetext{
${ }^{15}$ NIETZSCHE, F. Crepúsculo dos Ídolos, "O que devo aos antigos”, § 4, p. 105-106.
} 
Plenitude do êxtase, do entusiasmo, da possessão, mas também bemaventurança do vinho, alegria da festa, prazer do amor, felicidade do cotidiano, Dionísio pode trazer tudo isso se os homens souberem acolhê-lo, e as cidades, reconhecê-lo; assim como pode trazer infelicidade e destruição, se negado. Mas em nenhum dos casos ele vem para enunciar uma sorte melhor no Além. Ele não preconiza a fuga para fora do mundo, nem pretende trazer às almas, através de um modo de vida ascético, o acesso à imortalidade. Os homens devem, pelo contrário, aceitar sua condição mortal, saber que não são nada diante das forças que transbordam de toda parte e que têm o poder de esmagá-los. Dionísio não faz exceção à regra. Seu fiel submete-se a ele como a uma força irracional que o ultrapassa e dele dispõe; o deus não tem contas a prestar; estranho a nossas normas, a nossos usos, a nossas preocupações, além do bem e do mal, supremamente suave ou supremamente terrível, ele brinca de fazer surgir à nossa volta e dentre de nós, as múltiplas figuras do Outro. ${ }^{16}$

Nos ritos dionisíacos, legitimava-se a integração imediata entre as esferas do "eu" e do "outro", circunstância que abolia qualquer diferenciação ontológica entre os seres. Existe apenas uma vida, que se manifesta necessariamente em indivíduos e que é a mesma em cada um deles. A prática dionisíaca conduz a um processo que suprime a esclerosada separação do indivíduo em relação ao mundo externo e ao grande corpo da natureza, por consequência da divisão da vida em múltiplos fragmentos individualizados pelas contingências da existência, que impõe esse divórcio ontológico entre os seres vivos. Conforme aponta Michel Maffesoli,

Imitando a desordem e o caos através da confusão dos corpos, o mistério dionisíaco funda periodicamente uma nova ordem, e sublinha também a preeminência do coletivo sobre o individualismo e seu correlato racional, que é o social ${ }^{17}$

Mediante a encarnação dessa invencível força dionisíaca, ocorre então o desvanecimento do indivíduo na natureza, de modo que ele participa do processo criador da vida. Com o espírito dionisíaco, desaparece a individuação, o homem sentese idêntico a tudo o que vive e sofre, sente-se uma vontade esparsa em todo o universo. Aliás, esta citada diferenciação entre as diversas formas de vida ocorreria por causa de

\footnotetext{
${ }^{16}$ VERNANT, Jean-Pierre \& VIDAL-NAQUET, Pierre. Mito e Tragédia na Grécia Antiga, p. 359.

${ }^{17}$ MAFFESOLI, M. A Sombra de Dioniso, p. 16.
} 


\section{RENATO NUNES BITTENCOURT}

uma ilusão fenomênica da percepção humana, pois que, para além de toda imagem espaço-temporal, haveria a matriz primordial da existência, o "Uno Originário" [Ureinem], identificado por Nietzsche como a expressão metafísica do próprio princípio dionisíaco. ${ }^{18}$ Conforme dito no início desse tópico, o conceito de "Uno Originário" reflete a marcante influência da filosofia de Schopenhauer sobre Nietzsche, conforme podemos constatar através de uma leitura pormenorizada d' O Nascimento da Tragédia, perdendo, no entanto, a conotação marcadamente metafísica concedida outrora pela interpretação schopenhaueriana, tornando-se então o núcleo engendrador do qual se destacam todas as formas de vida.

A vivência dionisíaca faz valer a fusão entre todos os indivíduos, através das suas danças e dos seus cantos sagrados, tendo em vista a celebração da grande unidade da natureza, a mãe originária de todas as coisas existentes, conforme explicita Nietzsche, na sua interpretação desse acontecimento extraordinário:

Sob a magia do dionisíaco torna a selar-se não apenas o laço de pessoa a pessoa, mas também a natureza alheada, inamistosa ou subjugada volta a celebrar a festa de reconciliação com seu filho perdido, o homem. Espontaneamente oferece a terra as suas dádivas $\mathrm{e}$ pacificamente se achegam as feras da montanha e do deserto. $\mathrm{O}$ carro de Dionísio está coberto de flores e grinaldas: sob o seu jugo avançam o tigre e a pantera. Se se transmuta em pintura o jubiloso hino beethoveniano à "Alegria" e se não se refreia a força de imaginação, quando milhões de seres frementes se espojam no pó, então é possível acercar-se do dionisíaco. Agora o escravo é homem livre, agora se rompem todas as rígidas e hostis delimitações que a necessidade, a arbitrariedade ou a "moda impudente" estabeleceram entre os homens. Agora, graças ao evangelho da harmonia universal, cada qual se sente não só unificado, conciliado, fundido com o seu próximo, mas um só, como se o véu de Maia tivesse sido rasgado e, reduzido a tiras, esvoaçasse diante do uno primordial. ${ }^{19}$

A vivência dionisíaca não compreendia a extinção da existência individual como um acontecimento digno de pesar, tampouco a própria vida como indigna de ser vivida, pois viver é celebrar continuamente essa fusão do humano com a natureza, mãe divina de todos os seres. Na perspectiva religiosa da vivência dionisíaca, esse culto, apesar dos

\footnotetext{
${ }^{18}$ NIETZSCHE, F. O nascimento da Tragédia, § 1, p. 31.

${ }^{19}$ NIETZSCHE, F. O nascimento da Tragédia, § 1, p. 31.
} 
seus excessos rituais, é testemunho do desmedido esforço da humanidade grega para romper violentamente a barreira que a separa do âmbito divino, libertando o indivíduo das suas próprias limitações existenciais.

Como o espírito dionisíaco requer a conciliação entre a esfera individual e a natureza, relação rompida abruptamente pela ordem social, em muitas circunstâncias essa fusão somente poderia se concretizar através da morte propriamente dita do indivíduo, morte essa que favorecia o renascimento dessa pessoa no âmago da natureza. Nessas condições, a morte e a vida seriam, de acordo com a visão de mundo dionisíaca, eventos inexoravelmente complementares, ainda que essa complementaridade manifestasse necessariamente um constante conflito de forças em sua organização interna, que ocasionava em diversas ocasiões a dilaceração da individualidade. Contudo, era esse intenso choque de potências que concedia significado e valor para cada um desses núcleos antagônicos da natureza.

A vida não subsiste senão porque a morte existe. Por conseguinte, a vida somente possui o seu valor através da compreensão imediata da existência da morte, e vice-versa. Morrer não é desaparecer, mas se integrar no mundo, na terra, que insaciavelmente produz novas singularidades; tal é o começo da morte, mas esta, em definitivo, é a condição de nova vida. A intuição trágica levada a cabo pelo dionisismo evidenciava que para além da vida organicamente limitada (Bios) do indivíduo existe a vida infinita (Zoé), que jamais se extingue. ${ }^{20} \mathrm{O}$ dionisíaco anseia pela vida intensiva, mágica, que não depende, necessariamente, de uma configuração orgânica, corporal e individual para se expressar, pois a sua vitalidade ontológica se expressa sempre de modo desmedido, para além dos limites da figuração.

Esse seria um dos principais aspectos resultantes da interação entre o apolíneo e o dionisíaco, jogo de forças que permitiu a formulação do espírito trágico entre os gregos antigos, pois que não havia o desejo incubado de se estabelecer a supressão de uma das expressões naturais em favor de outra pretensamente mais suportável, mas sim a legitimação incondicional desse imensurável embate cosmológico entre a placidez

\footnotetext{
${ }^{20}$ Ressaltemos que essa perspectiva é continuamente defendida por Karl Kerenyi no seu Dioniso, o culto dionisíaco como uma manifestação arquetípica de uma vida indestrutível. Além disso, Werner Jaeger também dedica importantes reflexões sobre o Zoé e o Bios na Paidéia, p. 967, considerando o primeiro conceito como o fenômeno natural da vida, enquanto o segundo é a vida considerada como unidade de vida individual, a que a morte põe termo, e também como subsistência.
} 


\section{RENATO NUNES BITTENCOURT}

apolínea e a desmedida dionisíaca, embate no qual se manifestava para aquele que fosse dotado de percepção intuitiva a visão trágica de que o conflito de forças naturais era condição indispensável para a continuidade da vida em seus múltiplos modos de expressão. O trágico não se forma numa relação do negativo e da vida, "mas na relação essencial da alegria e do múltiplo, do positivo e do múltiplo, da afirmação do múltiplo", conforme o comentário de Deleuze acerca desse tema. ${ }^{21}$ Essa oposição entre o apolíneo e o dionisíaco representa claramente a metáfora heraclitiana de que a "guerra" é o elemento gerador de todas as coisas, pois é a partir dessa oposição fundamental que toda a realidade se origina ${ }^{22}$. Se a sociedade manifesta nas suas instituições e nas suas manifestações cotidianas uma contínua emulação entre os indivíduos, isso se dá pela própria particularidade do princípio erístico que conduz o grande jogo do mundo. Conforme a bela interpretação de Nietzsche:

Só um grego era capaz de fazer dessa representação o fundamento de uma cosmodicéia; é a boa Éris de Hesíodo, transfigurada em princípio cósmico, é a ideia de competição dos gregos singulares e da cidade grega, transferida dos ginásios e das palestras dos agons artísticos, da luta dos partidos políticos e das cidades, para o mais universal, de maneira que a engrenagem das coisas nela gira ${ }^{23}$.

O culto dionisíaco proclamava dessa maneira a alegria incondicional pela vida, mesmo que esta, considerada enquanto expressão individual, porventura sucumbisse eventualmente no decorrer das suas práticas rituais, assim como pelo natural efeito transformador do tempo cronológico, que impõe o perecimento a tudo aquilo que existe. A morte nada mais seria do que a retorno do indivíduo àquele que seria em verdade o seu ponto de partida para a constituição de uma vida extensiva.

O aniquilamento do indivíduo, na prática dionisíaca, não representaria, portanto, a sombria extinção da vida, mas a possibilidade de que as suas partes extensivas se reconfigurassem em novos modos de expressão através do processo de contínua transformação dos elementos da natureza. Aproveitemos neste momento essas reflexões de Walter Friedrich Otto acerca do culto dionisíaco:

\footnotetext{
${ }^{21}$ DELEUZE, G. Nietzsche e a Filosofia, p. 29.

${ }^{22}$ HERÁCLITO, Fragmento 51 DK.

${ }^{23}$ NIETZSCHE, F. A Filosofia na Idade Trágica dos Gregos, § 5.
} 
Quando ele irrompe com o seu selvagem cortejo, volve o mundo primordial que desdenha todo limite e toda norma, pois lhes é anterior; mundo que não conhece hierarquia nem distinção dos sexos, pois, sendo vida entrelaçada com a morte, envolve e reúne a todos os seres, indiferentemente ${ }^{24}$.

A matéria constituinte das coisas, portanto, é viva, dotada de um poder divino imanente que lhe permite doar a energia criadora que proporciona o desenvolvimento e florescimento criativo de todos os seres. Eis o motivo pelo qual podemos dizer que morte e vida, no contexto do ritual dionisíaco, são duas instâncias plenamente interativas, pois que ambas dependem mutuamente uma da outra, a fim de que a existência como um todo possa se efetivar sem cisões. "Cada instante devora o precedente, cada nascimento é a morte de incontáveis seres, gerar, viver e morrer são uma unidade", conforme afirma Nietzsche acerca desse mistério assimilador presente na potência dionisíaca da natureza. ${ }^{25}$ Este é o sentido primordial do culto dionisíaco, o de demonstrar a existência de um poderoso ciclo vital existente no processo de criação e destruição das inúmeras formas de vida contidas no seio da natureza. Na visão trágica, vida e morte, ascensão e decadência formam um todo e, por isso, o sentimento trágico da vida não é recusa, mas aceitação do devir, adesão à morte e ao declínio. Declínio que não significa decadência ou destruição, mas um regresso ao fundo da vida do qual surgiram todas as coisas individualizadas. Tal como a sabedoria trágica de Heráclito expõe aos homens,

Este mundo, o mesmo de todos os seres, nenhum deus, nenhum homem o fez, mas era, é e será um fogo sempre vivo, acendendo-se em medidas e apagando-se em medidas. ${ }^{26}$

A morte, no culto dionisíaco, não é considerada como um acontecimento digno de tristeza e pesar, tampouco uma passagem condicional para um além-mundo, pois é um mecanismo necessário para a perpetuação da existência de todas as coisas, utilizado pela natureza matriz, para que a própria vida seja mantida. Senhor do duplo domínio da

\footnotetext{
${ }^{24}$ OTTO, W. F., Teofania, p. 162.

${ }^{25}$ NIETZSCHE, F. “O Estado Grego”, In: Cinco Prefácios para cinco livros não escritos, p. 49.

${ }^{26}$ HERÁCLITO, Fragmento 30 DK.
} 


\section{RENATO NUNES BITTENCOURT}

vida e da morte, Dionísio renasce continuamente de seu próprio aniquilamento para sempre recomeçar. Por conseguinte, a "cosmovisão" dionisíaca demonstra que, através da morte, apenas a existência individual é suprimida, mas o elemento configurador da vida permanece incólume. A crença numa dimensão puramente espiritual separada da natureza concreta, na qual haveria uma existência pessoal livre das condições intrínsecas da sensibilidade é um elemento absolutamente estranho ao sentido trágico da experiência dionisíaca, que estabelecia uma intensa percepção imanente da vida.

Penetrar nessa esfera sagrada na qual havia o entrelaçamento entre a dor divina e a fragmentação da vida na pluralidade individual representa para o grego trágico o desvelamento da realidade cósmica, livre de todas as ilusões da consciência fiada exclusivamente no âmbito da fria racionalidade. Imergir nessa dimensão arrebatadora da natureza era uma experiência que justificava toda a banalidade da vida corriqueira, pois que no momento da fusão entre o divino e o humano na experiência trágica, o homem grego se libertava de toda condição pessoal estabelecida. O seio da natureza soluça pelo seu despedaçamento em milhões de seres individualizados, aguardando ao retorno da unidade primordial ${ }^{27}$. A separação entre o humano e a natureza, expressão sagrada do divino, não é eterna, pois na própria extinção da configuração individual ocorria novamente essa fusão entre o ser humano e a força da natureza.

$\mathrm{Na}$ realização da tragédia grega a compreensão da unidade eterna da vida se revelava de maneira imediata para o espectador, extasiado pela visualização do sofrimento dionisíaco encarnado nas figuras dos grandes heróis míticos. A tragédia grega se configura como um tônico que reforçava o ânimo do espectador para a ação, para a criatividade contínua, para uma nova forma de experimentar a existência, mediante a alegria despertada através da compreensão da eternidade da vida. ${ }^{28}$ Por conseguinte, o objetivo principal da ética-estética da Tragédia Ática consistia em, mediante o arrebatamento do espectador diante da exibição dos terríveis sofrimentos do herói, motivar naquele o desabrochar de estados de grande exaltação jubilosa, através da existência do "consolo metafísico", conceito elaborado por Nietzsche como meio de

\footnotetext{
${ }^{27}$ NIETZSCHE, F. O nascimento da Tragédia, § 2, p. 34.

28 J. J. Bachofen, no Matriarcado, p. 155-156, faz um comentário do qual o pensamento nietzschiano certamente se nutriu: "Somente na eterna geração e na morte igualmente eterna reside a imortalidade, que não pode ser concedida ao indivíduo, mas só à estirpe enquanto tal."
} 
explicar o maravilhoso fenômeno que ocorria quando o espectador trágico, ao visualizar o padecimento do herói, percebia que a vida, apesar das suas contínuas transformações, permanecia incólume. ${ }^{29}$ Afinal, era o homem, enquanto expressão singularizada pela individuação, que se extinguia através do evento da morte, mas a existência da vida permaneceria indestrutível, pois o centro engendrador do conjunto das formas de vida se encontra fora das limitações do tempo e do espaço. Essa concepção evidencia o quão Nietzsche foi influenciado pela metafísica da morte schopenhaueriana:

Como as gotas pulverizadas da queda d'agua estrondosa mudam com rapidez de relâmpago enquanto o arco-íris, do qual elas são o sustentáculo, está fixo em calma imóvel, por completo imune a essa mudança incessante; assim permanece cada ideia, isto é, cada espécie de ser vivente, por completo intocada pela mudança contínua dos seus indivíduos ${ }^{30}$.

O consolo metafísico exercia um poder unificador entre a coletividade grega, pois que esta se compreendia como uma expressão coesa, abundante de força criadora capaz de proporcionar a perpetuação da cultura grega. Vendo-se como membro de uma grande unidade que supera a sua condição individual, aquele que imergia na consciência trágica se identificava dionisiacamente não apenas com o herói representado na cena, mas também com as pessoas ao seu redor, de modo que o indivíduo, encantado pela musicalidade sagrada do drama trágico, compreendia a alteridade mística proporcionada para toda pessoa que se encontrasse no seio da multidão. A alegria "metafísica" pelo trágico é uma transposição da sabedoria dionisíaca instintivamente inconsciente à linguagem da imagem; o herói, aparência suprema da vontade, é negado, para prazer nosso, porque é só aparência, e a vida eterna da vontade não é afetada por sua aniquilação. A consciência trágica percebe o mundo como uma experiência epifânica situada numa perspectiva mais ampla do que a da mera individuação. Segundo Nietzsche,

O consolo metafísico - com que, como já indiquei aqui, toda a verdadeira tragédia nos deixa - de que a vida, no fundo das coisas, apesar de toda a mudança das aparências fenomenais, é

\footnotetext{
${ }^{29}$ NIETZSCHE, F. O nascimento da Tragédia, § 7, p.55.

${ }^{30}$ SCHOPENHAUER, A. WWV/MVR, II, "Metafísica da Morte”, p. 94. 


\section{RENATO NUNES BITTENCOURT}

indestrutivelmente poderosa e cheia de alegria, esse consolo aparece com nitidez corpórea como coro satírico, como coro de seres naturais, que vivem, por assim dizer indestrutíveis, por trás de toda civilização, e que, a despeito de toda mudança de gerações e das vicissitudes da historia dos povos, permanecem perenemente os mesmos. ${ }^{31}$

Sob uma perspectiva ontológica, essa concepção significa que as inexprimíveis expressões da vida não se encerravam apenas na mera condição individual do ser humano, pois a natureza, identificada com a matriz dionisíaca do "Uno Originário", acolhe as múltiplas expressões de vida, transformando-as eternamente em novas configurações. Essas ideias apresentadas retiram da noção de "consolo metafísico" qualquer conotação transcendente ao mundo em que vivemos, pois o júbilo prometido àquele que vivencia a cena trágica ocorre no âmbito da própria imanência, sem que seja necessária a inserção do indivíduo em uma realidade puramente espiritual, desvinculada da imanência da terra.

Essa experiência mística é um "consolo" por excluir da afetividade do homem grego os sentimentos pessimistas e tristes diante da compreensão imediata da efemeridade da vida humana, revelando então que esta continua se recriando perpetuamente na natureza através das eras. Todavia, apesar do evidente poder tonificante contido na experiência do "consolo metafísico", não se pode deixar de citar que Nietzsche, na "Tentativa de Autocrítica" para $O$ nascimento da Tragédia, demonstra a sua aversão a tal conceito, considerando-o como um equívoco axiológico, em decorrência da influência de Schopenhauer na formulação de seu pensamento. De fato, o termo cunhado por Nietzsche, em decorrência do efeito trágico proporcionado pela sua experiência é um tanto inadequado para representar a amplitude de tal vivência; mas, independentemente da carga semântica demasiado romântica contida no conceito de "consolo metafísico", o que importa, na verdade, é o sentido maior dessa experiência, completamente alheia a um devaneio romântico ou idealista.

O "consolo metafísico", ao fazer o homem compreender que o conceito de "vida" não abarca a totalidade efetiva da própria vida, demonstra ao parcial olhar individual que ela permanece, porém, manifestada em muitas outras possibilidades

\footnotetext{
${ }^{31}$ NIETZSCHE, F. O nascimento da Tragédia, § 7, p. 55.
} 
expressivas que extrapolam a subjetividade singular. Esse conceito problematizado por Nietzsche de forma alguma pode ser interpretado na qualidade de um afeto que instiga no homem o desenvolvimento da resignação diante da terrível caráter efêmero do mundo, como pretendia Schopenhauer. ${ }^{32}$ Tal perspectiva resultaria em uma severa passividade diante do mundo, mas sim a possibilidade de instauração de um sentimento muito mais ativo e poderoso, que fizesse o ser humano, ao despertar na sua vida a sabedoria trágica, apreender a realidade do mundo sem se deixar limitar pelo medo diante da transformação ou pela injúria contra a natureza pelo fato de ter nascido, como preconizaria uma interpretação da existência norteada por princípios metafísicos. Peter Szondi, no seu Ensaio sobre o Trágico, nos fornece uma elucidação de grande importância sobre a mudança radical de Nietzsche em relação ao sistema de Schopenhauer na questão do efeito da cena trágica para a vida:

Em Schopenhauer, a vontade suprime a si mesma, por meio do processo trágico em que suas manifestações se dilaceram, tendo como efeito no espectador o abandono de si, a resignação graças ao conhecimento. Para Nietzsche, por sua vez, o dionisíaco irrompe de seu despedaçamento na individuação justamente como um poder indestrutível, que constitui então a "consolação metafísica" oferecida pela tragédia ${ }^{33}$.

\footnotetext{
32 SCHOPENHAUER, A. WWV/MVR, I, § 51. Devemos destacar que Schopenhauer, na sua hierarquização metafísica das belas-artes, ao eleger a Tragédia como a arte mais elevada dentre daquelas que representam imediatamente as Ideias, considerava que a tragédia moderna, influenciada pela visão de mundo cristã, seria superior à tragédia grega, pois esta demonstraria o embate do herói contra as leis divinas, a ordem estabelecida e o seu anseio de superar os seus limites mediante feitos extraordinários, enquanto aquela pretenderia exercer uma função apaziguadora do ânimo humano, mediante a demonstração de que o mundo, sendo intrinsecamente malévolo, não é o palco dos justos, dos honestos, mas dos pérfidos, e são esses que triunfam empiricamente. Todavia, cabe ao homem de boa vontade a resignação e a renúncia ao agir, pois somente assim ele pode obter a paz de espírito que tanto anseia, mediante a supressão do seu querer. Mais ainda, não deixa de se manifestar em tal perspectiva a confiança numa justiça eterna, que punirá noutro mundo os abusos da tirania, pois do momento em que é uma concepção baseada na moral cristã, um dos elementos promotores dessa firme resignação é justamente a esperança na ação equânime de uma instância divina a punir a maldade humana. Podemos encontrar um exemplo dessa perspectiva na cena final da tragédia Emília Galotti de G. E. Lessing, em que o pai da personagem título profere ao infame príncipe Gonzaga o discurso de que a justiça que não se realiza na Terra se realizará perante o julgamento divino, pois o soberano, na sua lascívia, empregou todos os recursos para saciar as suas inclinações sexuais diante da casta Emília Galotti, arruinando a sua esperança de obter um casamento feliz com o Conde Appiani pelo fato deste ter sido assassinado numa emboscada pelos sicários do soberano.

${ }^{33}$ SZONDI, P. Ensaio sobre o Trágico, p, 69.
} 


\section{RENATO NUNES BITTENCOURT}

A perpetuação da existência evidenciada pelo coro trágico é uma refutação de qualquer traço moralizante na vivência do espírito da tragédia grega, circunstância que leva a Nietzsche a afirmar que

É nesse coro que se reconforta o heleno com o seu profundo sentido das coisas, tão singularmente apto ao mais terno e ao mais pesado sofrimento, ele que mirou com olhar cortante bem no meio da terrível ação destrutiva da assim chamada história universal, assim como da crueldade da natureza, e que corre o perigo de ansiar por uma negação budista do querer. Ele é salvo pela arte, e através da arte salva-se nele - a vida. ${ }^{34}$

A potência dionisíaca representa simultaneamente o grande corpo da vida e as condições nutrícias pelas quais as expressões singularizadas podem se manifestar na natureza, pois Dionísio, na sua disposição trágica de retornar ao primado telúrico da existência, doa a sua vitalidade intrínseca para todos. O deus fragmentado, transformado em ar, água, terra e fogo, representa o estado da individuação, enquanto fonte e causa primordial de todo o sofrer, como algo em si rejeitável:

Do sorriso desse Dionísio surgiram os deuses olímpicos; de suas lágrimas, os homens. Nessa existência de Deus despedaçado tem Dionísio a dupla natureza de um cruel demônio embrutecido e de um brando e meigo soberano ${ }^{35}$.

Dionísio, produto do divino casamento entre o céu e a terra, é ao mesmo tempo governador clemente e homem feroz, trazendo consigo a promessa do próprio renascimento, que reunirá o mundo e acabará com a dolorosa existência limitada pela individuação. O desmembramento sagrado de Dionísio é o processo cósmico que permitirá a constituição da raça humana, e a grande dádiva desse acontecimento é que a carne divina de Dionísio, matéria-prima de nossa condição humana, faz com que portemos conosco a centelha divina da criação e da beleza. Como contribuição para essa questão, é importante destacar que, segundo a mitologia grega, o primeiro Dioniso, após ser despedaçado e deglutido pelos Titãs, é justiçado por Zeus, que pulveriza esses seres que cometeram essa ação terrível. A partir das cinzas dos Titãs, que de alguma maneira

\footnotetext{
${ }^{34}$ NIETZSCHE, F. O nascimento da Tragédia, § 7, p. 55.

${ }^{35}$ NIETZSCHE, F. O nascimento da Tragédia, § 10, p. 70.
} 
continham fragmentos do corpo devorado de Dionísio, Zeus constitui a raça humana, cuja matéria-prima, portanto, agrega na sua constituição o elemento divino e o elemento terreno. ${ }^{36}$ A celebração dionisíaca, seja no seu ritual omofágico noturno, seja nos seus preceitos iniciáticos dos mistérios ou na sua expressão musical protodramática, pretendia resgatar essa característica primordial de que a vida humana decorre de uma longínqua origem divina, olvidada ao longo das eras pelo contínuo desenvolvimento da consciência da individuação.

Nietzsche considera que a tragédia grega enunciava uma espécie de "doutrina misteriosófica", segundo a qual haveria uma unidade subjacente a tudo aquilo que existe de forma individualizada e separada entre si no mundo, a grande matriz natural dionisíaca. A divisão do ser humano na sua condição individual seria o motivo pelo "mal da existência", que pode ser resolvido mediante o restabelecimento da unidade natural. ${ }^{37}$ Podemos afirmar que decorre daí a ideia de que a existência do mundo se perpetuará ao longo das eras, sem qualquer traço normativo ou moral subjacente a esse processo. Inclusive, há uma grande sintonia de ideias entre os argumentos acima expostos acerca do "consolo metafísico" enunciado por Nietzsche e o Fragmento 52 DK de Heráclito, segundo o qual "O Tempo é criança jogando, brincando. Reinado de criança", pois que, em ambas as concepções, considera-se que as transformações contínuas da natureza decorrem sem que haja qualquer necessidade de expiação de uma pretensa culpa original por uma afronta cometida contra a ordem primordial do cosmos. Segundo Nietzsche,

Esse aspirar ao infinito, o bater de asas do anelo, no máximo prazer ante a realidade claramente percebida, lembram que em ambos os estados nos cumpre reconhecer um fenômeno dionisíaco que torna a nos revelar sempre de novo o lúdico construir e desconstruir do mundo individual como eflúvio de um arquiprazer, de maneira parecida à comparação que é efetuada por Heráclito, o Obscuro, entre

\footnotetext{
36 Conforme a argumentação de Junito de Souza Brandão em Mitologia Grega, V. II, p. 118, isso explicaria no ser humano a coexistência das disposições maléficas e benéficas: a nossa parte titânica é a matriz do "mal", mas, como os Titãs haviam devorado Dionísio, este se deve ao que existe de "bom" em cada um de nós. Essa perspectiva pode ser comparada com a ideia defendida por Michel Maffesoli em $A$ sombra de Dioniso, p. 78, na qual o autor afirma que Dioniso desmembrado e devorado pelos titãs serve de adubo ao crescimento dos homens.

${ }^{37}$ NIETZSCHE, F. O nascimento da Tragédia, $\S 10$, p. 70.
} 


\section{RENATO NUNES BITTENCOURT}

a força plasmadora do universo e uma criança que, brincando, assenta pedras aqui e ali e constrói montes de areia e volta a derrubá-los ${ }^{38}$.

A consciência trágica, eliminando todo princípio de moralização dos processos de constituição da existência, desemboca em uma percepção dos acontecimentos para além dos princípios de Bem e de Mal, resgatando assim a inocência da vida natural. Para Michel Maffesoli, “a vida como jogo é uma espécie de aceitação de um mundo tal como ele é, quer dizer, um mundo marcado pelo efêmero". ${ }^{39}$ Mesmo Homero, apesar de sua contínua afirmação da beleza e da dignidade gloriosa dos seus heróis, dissera que as gerações humanas desaparecem como as folhas das árvores. ${ }^{40} \mathrm{O}$ espírito trágico, todavia, não se lamuria diante desse acontecimento inexorável, proporcionando, pelo contrário, uma integração radical da individualidade no turbilhão cósmico da vida e dos seus múltiplos processos assimiladores. Conforme Nietzsche,

O dizer sim à vida, mesmo em seus problemas mais estranhos e difíceis; a vontade de viver, no regozijo sobre sua própria inexaurabilidade, e mesmo no próprio sacrifício de seus tipos mais altos - isso é o que chamei dionisíaco, isso é o que compreendi como a ponte para a psicologia do poeta trágico. Não com o fim de nos livrarmos do terror e da piedade, não com o fim de nos purgarmos de uma noção perigosa através de sua liberação veemente mas com o fim de sermos nós mesmos a eterna alegria de vir-a-ser, além do terror e da piedade - essa alegria que inclui até a alegria de destruir. ${ }^{41}$

Viver a perspectiva trágica é viver a satisfação de uma alegria primordial no jogo de criar e destruir o mundo individualizado, como faria uma criancinha mexendo displicentemente na areia do mar. Heráclito afirmara sabiamente que, para o deus são belas todas as coisas e boas e justas, mas os homens tomam umas como injustas, outras como justas. ${ }^{42}$ Aproveitando a força retórica dessa sentença, Nietzsche afirma que "tudo o que existe é justo e injusto e em ambos os casos é igualmente justificado". ${ }^{43} \mathrm{Na}$ ordenação natural das coisas, inexiste qualquer normatividade que exija prestação de

\footnotetext{
${ }^{38}$ NIETZSCHE, F. O nascimento da Tragédia, § 24, p. 142.

${ }^{39}$ MAFFESOLI, M. O Instante Eterno, p. 78.

${ }^{40}$ HOMERO. Ilíada, VI, vs. 146.

${ }^{41}$ NIETZSCHE, F. Ecce Homo, “O Nascimento da Tragédia”, § 3.

${ }^{42}$ HERÁCLITO. Fragmento DK 102.

${ }^{43}$ NIETZSCHE, F. O nascimento da Tragédia, § 9, p.69.
} 
contas pelos pretensos erros cometidos pelos indivíduos no decorrer das suas vidas.As inexoráveis transformações da natureza não expressam qualquer culpabilidade moral, pois a expressão da vida se encontra para além de qualquer esfera de valor coercitivo ou normativo que impõe um critério extrínseco de conduta ao ser humano. Importante destacar que, nessas condições, a perspectiva trágica da vida defendida por Nietzsche mediante a influência recebida do pensamento de Heráclito demonstra uma intensa contraposição ao pensamento de Anaximandro, segundo o qual todas as formas singularizadas de vida, em decorrência da prática de uma falta originária cometida no próprio ato da individuação, encontram a punição cósmica através da própria ordem do tempo, que se encarrega de exercer essa ação reparatória sobre os seres vivos através da morte. Eis a sentença lapidar: "De onde as coisas tiram a sua origem, aí devem também perecer, segundo a necessidade; pois elas têm de expiar e ser julgadas pelas suas injustiças, de acordo com a ordem do tempo". ${ }^{44}$

A sentença de Anaximandro denota um acentuado pessimismo diante da fragilidade da condição humana, pessimismo esse que é potencializado pela presença de um argumento moral contra a própria existência humana, intrinsecamente culpável diante da ordem cósmica. O devir é a emancipação criminosa em relação ao ser eterno, como uma iniquidade que tem de ser expiada com a ruína. Tudo o que uma vez entrou no devir torna a perecer, quer pensemos na vida humana, quer na água, ou no calor e no frio; onde quer que se constatem propriedades definidas, pode profetizar-se, segundo uma imensa prova experimental, o desaparecimento dessas propriedades. A individualização no devir é uma manifestação da hybris. A eternidade e a imortalidade do ser primordial radicam na sua indeterminação e todo o ser finito é o início de uma decadência, pois o que tem qualidades definidas está sujeito a evoluir e a morrer. Consequentemente, o devir é necessariamente punido e a existência da multiplicidade expia-se pelo sofrimento e pela morte da individuação. Se há uma unidade eterna, como é que a multiplicidade é possível? A resposta para essa indagação se encontra no caráter contraditório dessa multiplicidade, que a si mesma se devora e se nega. Essa disposição axiológica acerca da existência é similar ao mundo de sombras operado pela visão

\footnotetext{
${ }^{44}$ ANAXIMANDRO. Fragmento DK 1.
} 
titânica de mundo. Nietzsche continua a sua reflexão sobre a tragicidade pessimista de Anaximandro ao indagar de forma retórica:

De onde vem esse incessante devir e parturir, de onde procede essa contração dolorosa no rosto da natureza, essa lamentação fúnebre infindável que ressoa através de todas as esferas da existência? Deste mundo de iniquidade, de descaída ousada da unidade primordial das coisas, Anaximandro refugia-se numa fortaleza metafísica, a partir da qual, agora debruçado, deixa deslizar em volta o seu olhar para, finalmente, depois de um silêncio meditativo, fazer essa pergunta a todos os seres: "Qual é o valor da vossa existência? E se nada vale, por que existis? É por vossa culpa, disso me apercebo eu, que permaneceis nesta existência. Haveis de a expiar pela morte. Vede como a vossa terra murcha, os mares diminuem e secam; o marisco nas montanhas mostram até que ponto já secaram; o fogo já destrói o vosso mundo, que acabará por desaparecer no vapor e no fumo. Mas sempre de novo se edificará esse mundo de instabilidade: quem poderá libertar-vos da maldição do devir?"45

Como superar esse mal-estar moral evidenciado por Anaximandro na sua filosofia? Através da alegria e da inocência, pois o processo dionisíaco da existência se assemelharia profundamente a uma atividade lúdica, desprovida de responsabilidade moral ou de um caráter teleológico que visa um objetivo ulterior a ser realizado neste ou mesmo noutro mundo, mediante o contínuo aprimoramento da consciência espiritual enquanto expressão moral do indivíduo. A Criança de Heráclito, representando o poder assimilador de Dionísio para além das relações morais de responsabilidade, dever e culpabilidade, silencia a tristeza de Anaximandro diante da suposta tenebrosidade do mundo no qual estamos inseridos e no qual expiamos continuamente nossas faltas contra a ordem divina. A lei da vida se cumpre no deus cantante, pois nele não culpa nem redenção, mas sim a inocência do devir. Tanto a criança, como o artista e o fogo apontam para a ideia de leveza, vivacidade, expansibilidade ou, numa palavra, irresponsabilidade. Ao modo do artista, a criança se revela incansável no seu jogo de construção e destruição, de ajuntamento e dispersão, de retomada e interrupção, de acabamento e recomeço.

Heráclito é então o filósofo que, impulsionado pela visão trágica de mundo, permite a depuração da sabedoria grega dos elementos que dirigiam a consciência

\footnotetext{
${ }^{45}$ NIETZSCHE, F. A Filosofia na Idade Trágica dos Gregos, § 4, p. 35-36.
} 
humana para o seu aspecto aterrador, fazendo compreender a todos, no entanto, que não estamos livres de forma alguma da dissolução e da morte, mas que tal acontecimento não é signatário de uma punição cósmica, mas a necessidade intrínseca do ciclo vital do mundo que requer a transformação e renovação constante das formas de vida. Abolindo uma perspectiva moral sustentada por uma axiologia metafísica, Heráclito não estabelece qualquer dicotomia no mundo em que estamos, pois tudo faz parte de uma grande unidade fundamental que, apesar das suas aparentes contradições, manifesta em sua estrutura vital a mais perfeita justiça. Para Nietzsche, Heráclito teria intuído a potência sagrada inerente ao processo vital do Tempo, pueril:

Neste mundo, só o jogo do artista e da criança tem um vir à existência e um perecer, um construir e um destruir sem qualquer imputação moral em inocência eternamente igual. $\mathrm{E}$, assim como brincam o artista e a criança, assim brinca também o fogo eternamente ativo, constrói e destrói com inocência - e esse jogo joga-o o Aion consigo mesmo. Transformando-se em água e em terra, junta, como uma criança, montinhos de areia à beira-mar, constrói e derruba: de vez em quando, recomeça o jogo. Um instante de saciedade: depois, a necessidade apodera-se outra vez dele, tal como a necessidade força o artista a criar. Não é a perversidade, mas o impulso do jogo sempre despertando que chama outros mundos à vida. Ás vezes, a criança lança fora o brinquedo: mas depressa recomeça a brincar com uma disposição inocente. Mas, logo que constrói, liga e junta as formas segundo uma lei e em conformidade com uma ordem intrínseca. ${ }^{46}$

A sabedoria alcançada com a identificação etológica com Dionísio é a do devir permanente das coisas e do jogo aleatório da natureza, aparentemente sem sentido, do desfazer de todo o existente. Nietzsche considera que "o prazer que o mito trágico gera tem sua pátria idêntica à sensação prazerosa da dissonância na música. $\mathrm{O}$ dionisíaco, com o seu prazer primordial percebido inclusive na dor, é a matriz comum da música e do mito trágico" ${ }^{47}$. A visão trágica de mundo nos faz compreender intimamente que o valor da existência se encontra presente em si mesmo, no seu próprio matiz ontológico, descartando-se então a pertinência de qualquer especulação transcendente de mundo, na qual se creria na existência de outra dimensão da realidade.

\footnotetext{
${ }^{46}$ NIETZSCHE, F. A Filosofia na Idade Trágica dos Gregos, § VII, p. 49-50.

${ }^{47}$ NIETZSCHE, F. O nascimento da Tragédia, § 24, p. 141.
} 


\section{RENATO NUNES BITTENCOURT}

A "serventia" axiológica e ética do "consolo metafísico" para a vida cultural dos gregos consistia em demonstrar ao espectador trágico que a existência marcada pela individuação é uma espécie de distorção da compreensão gnosiológica da realidade proporcionada pelo véu de ilusão que cobre todas as coisas, uma vez que as formas individualizadas existentes no mundo são meros desdobramentos da fonte matriz da natureza, desdobramentos que não possuem existência singularizada em um âmbito originário. Para Nietzsche,

No estado de "estar fora de si", do êxtase, somente um passo é ainda necessário: que não voltemos a nós mesmos novamente, mas entremos em um outro ser, de modo que nos portemos como encantados. Por isso, o profundo espanto diante do espetáculo do drama toca a última profundeza: vacila o solo, a crença na indissolubilidade e na fixidez do indivíduo. ${ }^{48}$

Além das figuras fenomênicas, separadas individualmente pelas categorias do espaço e do tempo, se encontra a grande unidade cósmica da vida, que rompe as cadeias limitadoras da extensividade material e da própria individualidade. $\mathrm{O}$ "consolo metafísico" seria uma espécie de apanágio obtido pelo espectador capaz de perceber intuitivamente a condição extraordinária da existência, cuja fonte vital jamais se esgota, mesmo diante da supressão das suas inúmeras formações individuais. Tratava-se, portanto, de uma experiência mística na qual o caráter sagrado da vida se revelava ao íntimo do indivíduo, sem que houvesse qualquer mediação da racionalidade lógica nessa experiência. Nietzsche destaca que

O sátiro, enquanto coreuta dionisíaco, vive numa realidade reconhecida em termos religiosos e sob a sanção do mito e do culto. Que com ele comece a tragédia, que de sua boca fale a sabedoria dionisíaca da tragédia, é para nós um fenômeno tão desconcertante como, em geral, o é a formação da tragédia a partir do coro. Talvez conquistemos um ponto de partida para a nossa indagação, se eu introduzir a afirmação de que o sátiro, esse ser natural fictício, está para o homem civilizado na mesma relação que a música dionisíaca está para a civilização [...] Da mesma maneira, creio eu, o homem civilizado grego sente-se suspenso em presença do coro satírico; e o efeito mais imediato da tragédia dionisíaca é que o estado e a sociedade, sobretudo o abismo entre um homem e outro, dão lugar a

\footnotetext{
${ }^{48}$ NIETZSCHE, F. “O Drama Musical Grego”, p. 55-56.
} 
um superpotente sentimento de unidade que reconduz ao coração da natureza. ${ }^{49}$

Esse miraculoso prazer estético decorrente da percepção trágica da existência representa a manifestação insuperável da alegria dionisíaca. Regalando-se nessa percepção mística que supera os tênues limites da individuação, o homem trágico ri da sua própria finitude extensiva, condição que não é mais digna de vitupério, pois há algo nele que é eterno, permanecendo continuamente nos demais viventes. O "consolo metafísico" consistiria, portanto, numa espécie de grande riso da consciência trágica diante da cessação do medo e da angústia do indivíduo pela ameaça do seu aniquilamento, circunstância que resultaria na sua imersão numa espécie de grande "vazio cósmico", que demonstraria a falta de um significado moral genuíno da vida. Para Deleuze, "Rir é afirmar a vida e, na vida, até o sofrimento. Jogar e afirmar o acaso e, do acaso, a necessidade. Dançar é afirmar o devir e, do devir, o ser." ${ }^{50}$ Esse riso trágico diante da vitória sobre o pessimismo não expressa sarcasmo, mas sim a mais pura gratidão ao poder configurador da natureza pelo fato de ser concedida a existência ao indivíduo, que em sua condição intrínseca expressa criativamente a vitalidade cósmica que nele se manifesta.

\section{Considerações Finais}

Conforme vimos no decorrer deste artigo, tanto a dita "metafísica da morte" de Schopenhauer como a visão trágica de Nietzsche apresentam convergências axiológicas fundamentais. Apesar de Nietzsche, em sua maturidade intelectual, romper com o pensamento schopenhaueriano, é indiscutível que seu antigo mentor espiritual influenciou sobremaneira a formação de seu pensamento trágico. Por conseguinte, para além de todo pessimismo prático, Schopenhauer considera que somente a vida individual é suprimida pela morte física do corpo, pois sua essência, a Vontade, permanece eterna em todos os seres vivos; além disso, a energia vital constituinte dos organismos não se dissipa, manifestando-se na natureza circundante que absorve essa

\footnotetext{
${ }^{49}$ NIETZSCHE, F. O nascimento da Tragédia, § 7, p. 55.

${ }^{50}$ DELEUZE, G. Nietzsche e a Filosofia, p. 255.
} 


\section{RENATO NUNES BITTENCOURT}

potência energética. Nietzsche, por sua vez, ao associar a unicidade da existência ao cerne dionisíaco da natureza, estabelecerá uma perspectiva que compreende a perpetuação da vida para além das aparências finitas. Desse modo, a morte individual é apenas uma etapa cosmológica da grande vida dionisíaca, que agrega toda a existência. O princípio de individuação é o mantenedor da ilusão da consciência individual como uma instância separada das demais configurações existenciais, promovendo ainda o anseio egocêntrico por uma conservação incólume da personalidade individualizada em uma postulada vida espiritual. Ora, como não temos qualquer certeza daquilo que porventura existe após a dissolução física do corpo, as hipóteses de Schopenhauer e de Nietzsche promovem uma compreensão filosófica que evidencia que algo de cada um de nós não deixa jamais de existir. Mais do que uma filosofia moral do consolo, trata-se de uma radical perspectiva da imanência ética de uma vida poderosamente criadora.

\section{Referências bibliográficas}

ANAXIMANDRO. "Fragmentos" In: In: Vol. Pré-Socráticos, Col. "Os Pensadores". Trad. de José Cavalcante de Souza. São Paulo: Nova Cultural, 2000.

BACHOFEN. J. J. El Matriarcado - una investigación sobre la ginecocracia en el mundo antiguo según sua naturaleza religiosa y jurídica. Trad. Esp. de Maria del Mar Llinares Garcia. Madrid: Akal, 2007.

BRANDÃO, Junito de Souza. Mitologia Grega, Vol. II. Petrópolis: Vozes, 1987.

DELEUZE, Gilles. Nietzsche e a Filosofia. Trad. de António M. Magalhães. Porto: RésEditora, 2001.

ÉSQUILO. Oréstia [Agamêmnon, Coéforas, Eumênides] Trad. de Mário da Gama Kury. Rio de Janeiro: Jorge Zahar, 2003.

HERÁCLITO. "Fragmentos". In: Vol. Pré-Socráticos, Col. "Os Pensadores". Trad. de José Cavalcante de Souza. São Paulo: Nova Cultural, 2000.

HOMERO. Ilíada. Trad. de Carlos Alberto Nunes. Rio de Janeiro: Ediouro, 2002.

JAEGER. Werner. Paidéia: a formação do homem grego. Trad. de Artur M. Parreira. São Paulo: Martins Fontes, 1995.

LESSING, G. E. Emilia Galotti / Minna von Barnheim ou a felicidade do soldado. 
Trad. de Marcelo Backes. Porto Alegre: Mercado Aberto, 1999.

KERENYI, Karl. Dioniso: imagem arquetípica da vida indestrutível. Trad. de Ordep Serra. São Paulo: Odysseus, 2002.

MAFFESOLI, Michel. O Instante eterno: o retorno do trágico na sociedade pós-moderna. Trad. de Rogério de Almeida e Alexandre Dias. São Paulo: Zouk, 2004.

. A sombra de Dioniso - contribuição a uma sociologia da orgia. Trad. de Rogério de Almeida. São Paulo: Zouk, 2005.

NIETZSCHE, Friedrich. Cinco Prefácios para cinco livros não escritos. Trad. de Pedro Süssekind. Rio de Janeiro: Sette Letras, 1996.

. Crepúsculo dos Ídolos ou como se filosofa com o martelo. Trad. de Paulo César de Souza. Companhia das Letras: São Paulo: 2006.

Ecce Homo - como alguém se torna o que se é. Trad. de Paulo César de Souza. São Paulo: Companhia das Letras, 2001.

. A Filosofia na Idade Trágica dos Gregos. Trad. de Maria Inês Madeira Andrade. Lisboa: Ed. 70, 2002.

O nascimento da Tragédia ou helenismo e pessimismo. Trad. de J. Guinsburg. São Paulo: Companhia das Letras, 1996.

A visão dionisíaca de mundo e outros textos [Sócrates e a Tragédia e $O$ Drama Musical Grego]. Trad. de Marcos Sinésio Pereira Fernandes e Maria Cristina dos Santos de Souza. Martins Fontes: São Paulo: 2005.

OTTO, Walter Friedrich. Teofania: o espírito da religião dos gregos antigos. Trad. de Ordep Serra. São Paulo: Odysseus, 2006.

SCHOPENHAUER, Arthur. Metafísica do Amor/Metafísica da Morte. Trad. de Jair Barboza. São Paulo: Martins Fontes, 2000.

O Mundo como Vontade e como Representação. Trad. de Jair Barboza. São Paulo: Ed. UNESP, 2005.

SZONDI, Peter. Ensaio sobre o Trágico. Trad. de Pedro Süssekind. Rio de Janeiro: Jorge Zahar, 2004

VERNANT, Jean-Pierre \& VIDAL-NAQUET, Pierre. Mito e Tragédia na Grécia Antiga. Trad. de Anna Lia A. de Almeida Prado, Filomena Yoshie, Hirata Garcia, Maria M. Cavancante, Bertha H. Gurovitz e Hélio Gurovitz. São Paulo: Perspectiva, 1999. 
RENATO NUNES BITTENCOURT

Recebido: $24 / 12 / 13$

Received: $12 / 24 / 13$

Aprovado: 20/01/14

Approved: 01/20/14 